\title{
Obituary
}

\section{Alfred Rupert Hall (26 July 1920-5 February 2009) and Marie Boas Hall (18 October 1919-23 February 2009)}

\author{
J.V. FIELD*
}

The deaths of Rupert and Marie Hall prompt reflections not only on their work and its influence but also on the fact that what is now recognized as the discipline of the history of science is relatively new. Rupert and Marie came from very different backgrounds, but each exemplifies certain expectations about what it meant to be a historian of science in the years immediately following the end of the Second World War.

Rupert was born in Basford (between Stoke-on-Trent and Newcastle under Lyme), where some houses had a view over the canal and the Wedgwood factory at Etruria. Rupert's father, who had served in the infantry in the First World War, was employed in a shoe factory, first at the bench but later as a supervisor and salesman. The family moved to Leicester, where Rupert attended Alderman Newton's School, which had links with Christ's College, Cambridge. Alumni included C.P. Snow and, more recently, J.H. Plumb. Rupert had been interested in science at school - and his earliest acquaintance with a historical treatment of the subject came through borrowing a copy

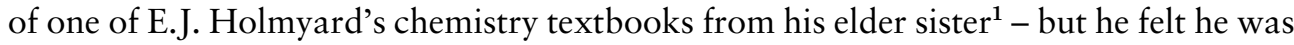
better prepared to read history. He won a minor scholarship, which was topped up by a grant from the local council, making it possible for him to go up to Christ's in 1938. The Second World War began on 3 September 1939, initially as a conflict between European powers, and Rupert left Cambridge in June 1940, having taken Part I of the History Tripos. He enlisted on 19 September 1940, aged twenty, giving his preferences, in order, as Royal Signals, Royal Artillery and Infantry. The second choice may hint at research work to come, but he got his first choice and a childhood interest in radios eventually

* Dr J.V. Field, School of History of Art, Film and Visual Media, Birkbeck, 43 Gordon Square, London WC1H 0PD. Email: jv.field@hist-art.bbk.ac.uk.

I am grateful to Frank A.J.L. James for help in thinking through what I wanted to say, and to Clarissa Thomas (née Hall) for answering questions and supplying copies of documents such as her father's Army records. Rupert and Marie Hall's papers are now in the Archives at Imperial College London.

1 A. Rupert Hall, 'How I became an historian of science and the author of books: a sidelight on the twentieth century', typescript, $c .1981$. The title of the Holmyard book is not specified but the work seems likely to have been either one of the many editions of An Elementary Chemistry or Chemistry for Beginners (1930). 
blossomed into what he regarded as his most significant wartime exploit: setting up a permanent radio link between Baghdad and London.

Lieutenant Hall was demobilized in November 1945 and returned to Cambridge to set up home for the first time with his wife - in December 1941 he had married Annie Hughes, whom he had known since childhood as a schoolfriend of his sisters - to take Part II of the History Tripos and then obtain a doctorate. His thesis, on ballistics in the seventeenth century, became his first published book, identified by its subtitle as 'a study in the relations of science and war'. ${ }^{2}$ He obtained an assistant lectureship in the History Department in 1950, followed by a lectureship in 1953. In the 1930s Joseph Needham and others had suggested history of science should be taught at Cambridge, but the war had put everything on hold. ${ }^{3}$ Rupert's lectures, partly developed from ideas put forward by Herbert Butterfield in The Origins of Modern Science (1949), were published in 1954 as The Scientific Revolution, a highly readable book that became a staple of reading lists for many years to come. ${ }^{4}$ Reflecting on his choice of subject, about forty years later, Rupert noted that at the time there was a generally positivistic attitude to science, and it was given great cultural importance. ${ }^{5}$ The belief in science as a progressive force can be seen very clearly in the treatment of scientific issues in the Festival of Britain in $1951 .^{6}$

In 1948, Rupert had been given the task of setting up a museum of the history of science based on the collection of scientific instruments given to the university by Robert Stewart Whipple. His suitability had been questioned on the grounds that Rupert was not a scientist. ${ }^{7}$ In the late 1950 s Charles Singer raised the same objection to Rupert's being considered a possible candidate for a chair in history of science at

2 A. Rupert Hall, Ballistics in the Seventeenth Century: A Study in the Relations of Science and War with Reference Principally to England, Cambridge: Cambridge University Press, 1952.

3 For details see Anna-K. Mayer, "Setting up a discipline, II: British history of science and "the end of ideology", 1931-1948', Studies in History and Philosophy of Science (2004) 35, pp. 41-72.

4 A. Rupert Hall, The Scientific Revolution 1500-1800, London: Longmans, 1954, 2nd edn 1962, revised as The Revolution in Science 1500-1750, 1983. On the choice of title see A. Rupert Hall, 'Retrospection on the Scientific Revolution', in J.V. Field and F.A.J.L. James (eds.), Renaissance and Revolution: Humanists, Scholars, Craftsmen and Natural Philosophers in Early Modern Europe, Cambridge: Cambridge University Press, 1993, pp. 239-249. On the relationship with Butterfield see A. Rupert Hall, 'Eloge: Sir Herbert Butterfield, 7 October 1900-20 July 1979', Isis (1981) 72, pp. 90-91.

5 [Scott Mandelbrote], Interview with A. Rupert Hall, Metascience (1994), new series, 5, pp. 77-84. The text is said to have been edited and I found the interviewee's style of expression and choice of topics so unlike what I already knew of him that I recommend anyone intending to make serious use of this material to consult the original tapes, held in the Codrington Library, All Souls College, Oxford.

6 A late manifestation of this spirit is found in a series of television programmes about the history of science, later published as a book, by one of the scientists behind the Festival of Britain, Jacob Bronowski, The Ascent of Man, London: British Broadcasting Corporation, 1973, several reprints.

7 See Joseph Needham's notes on a committee meeting of 3 June 1948 and a subsequent exchange of letters between him and Charles Singer, printed in Frances Willmoth (ed.), 'Documents from the founding and early history of the Whipple Museum', in Liba Taub and Frances Willmoth (eds.), The Whipple Museum of the History of Science: Instruments and Interpretations, to Celebrate the Sixtieth Anniversary of R.S. Whipple's Gift to the University of Cambridge, Cambridge: Cambridge University Press, 2006, pp. 11-55, especially pp. 32-36. 
Imperial College London, though by then they had worked together as authors and editors of the Oxford History of Technology. ${ }^{8}$

Marie Boas was born in Massachusetts. Her parents, Ralph Boas and Louise Schulz, taught English at Wheaton, a liberal arts college in the small town of Norton near Boston, and together wrote many books on literary subjects. Her uncle George Boas was a distinguished historian of ideas; her elder brother Ralph, whom she admired and looked up to, went on to become a noted mathematician. Marie left high school at sixteen and entered Wheaton College, where the rules prescribed English and a science subject. Many years later she recollected that she chose chemistry rather than physics because the teacher was better. ${ }^{9}$

In the event, Marie went on to study chemistry at Radcliffe College (then a feminine subsidiary of Harvard). Her studies were interrupted in 1939 when her parents, believing the visit could not be postponed because war was imminent, took her with them to Europe. While in London, Marie made her first visit to the British Museum Library, accompanying her mother, who was doing research for a life of Shelley. The Boas family arrived back in Boston on 3 September 1939. Marie took her degree in chemistry in 1940 and her master's in 1942.

Following the near total destruction of its Pacific Fleet at Pearl Harbor (6 December 1941) the US had declared war on Japan, and Germany had promptly declared war on the US. Marie's war work began with wiring up radios, then (when her employers noticed she could write clear English) writing instruction manuals to be used by the Army Signals Corps. Writing skills then took her to the technical manual section of the Massachusetts Institute of Technology Radiation Laboratory, which worked on radar (thanks to the invention of the cavity magnetron, this included airborne radar). After the end of hostilities, in August 1945, Marie was transferred to the Historian's Office, run by Henry Guerlac, whose purpose was to write a general history of the secret wartime work carried out at the laboratory. Guerlac had become involved because he was a historian of science ${ }^{10}$ and when the history was completed, under the title Radar in World War Two, he accepted a post teaching history of science at Cornell University, taking Marie with him as his research student. Her thesis, 'Robert Boyle and the corpuscular philosophy: a study of theories of matter in the seventeenth century', was accepted by the university in 1949, and, in slightly modified form, published by George Sarton in Osiris three years later. ${ }^{11}$

There was considerable enthusiasm for history of science in the US, but few posts dedicated to it. Marie found herself teaching American history, at the University of

8 Charles J. Singer, E.J. Holmyard, A. Rupert Hall and T.I. Williams (eds.), A History of Technology, 7 vols., Oxford: Clarendon Press, 1954-1984; see also A. Rupert Hall, 'Eloge: Charles Joseph Singer (1876-1960)', Isis (1960) 51, pp. 588-590.

9 Marie Boas Hall, 'How the partnership of Hall \& Hall came into existence: the junior partner's tale', typescript, possibly a transcript from a recording, c.1981.

10 On his career see Marie Boas Hall, 'Eloge: Henry Guerlac, 10 June 1910-29 May 1985', Isis (1986) 77, pp. 504-506.

11 Marie Boas Hall, 'Recollections of a history of science guinea pig', Isis (1999) 90, pp. 568-583. See also Marie Boas, 'The establishment of the mechanical philosophy', Osiris, 1st Series, 10 (1952), pp. 412-541; reprinted with modifications as The Mechanical Philosophy, New York: Arno, 1981. 
Massachusetts (Amherst) and then from 1952 at Brandeis, while her research interests continued to be in the history of science, specifically in the history of theories of matter. Here her methods resembled Rupert's. She read and admired his account of Newton's early notebook ${ }^{\mathbf{1 2}}$ - Guerlac had requested an offprint and on receiving two had passed the other one to Marie. It was perhaps his background in general history that made it seem natural to Rupert to make use of manuscript sources, which were easily found in Cambridge, and it was perhaps because of her literary background that using manuscript material seemed natural to Marie. But this made Rupert and Marie exceptional among historians of science at the time. They were also unusual in making extensive and explicit use of primary sources - that is, writings by natural philosophers and mathematicians of the period under consideration. Such use of primary material - something we now take for granted - is one of the characteristics that Marie praised in her review of The Scientific Revolution. ${ }^{13}$ Moreover, Marie shared Rupert's admiration for the work of Alexandre Koyré, who (I simplify!) recommended close reading of texts to search out the ideas underlying scientific theories. Rupert had read Koyré's Etudes Galiléennes (1939) in about 1949, and had found its approach a refreshing contrast to 'the dull treatment of the history of science that I found in so many articles and books, essentially consisting of the establishment of facts' ${ }^{14}$

It seems that Rupert and Marie first met in 1951, when Marie had decided to spend some of her savings on a visit to London to read Boyle papers in the Royal Society. Her friend Thomas S. Kuhn, whom she described as 'then an inconspicuous young lecturer at Harvard' (where he taught physics), suggested she should contact Hall, since they seemed to have much in common. ${ }^{15}$ This must surely count as one of his more acute historical insights.

Rupert and Marie were married in 1959, soon after Rupert's first marriage was dissolved. Rupert left Cambridge to join Marie at the University of California in Los Angeles (UCLA), where she had got her first job specifically as a historian of science. In 1961 they moved to the University of Indiana, and then, in 1963, Rupert took up the newly created chair in history of science at Imperial College London, with Marie as his only member of staff, initially as a senior lecturer but becoming a reader the following year. The correspondence relating to his appointment shows that he had strong support from Herbert Butterfield and Joseph Needham. The Halls remained at Imperial until their retirement in 1980 .

At Imperial College, the Halls set up postgraduate course in the history of science (taught by Rupert and Marie) and the history of technology (after 1966 largely taught by the new third member of the department, Norman Smith, though with some participation by Rupert and visiting lecturers). There were also undergraduate lectures. Any aspiring $\mathrm{PhD}$ student was strongly encouraged to attend the MSc lectures first (which

12 A. Rupert Hall, 'Sir Isaac Newton's notebook, 1661-65', Cambridge Historical Journal (1949) 9, pp. 239-250.

13 Marie Boas, review of A. Rupert Hall, The Scientific Revolution 1500-1800, London: Longmans, Green, 1954, in Isis (1955) 46, pp. 304-305.

14 A. Rupert Hall, op. cit. (1).

15 Marie Boas Hall, op. cit. (9). 
I believe many found very useful). As teachers the Halls were inspiring, painstaking, approachable and kind. Moreover, while historiographical storms raged outside, they never made the slightest move to impose any particular style on their students' work.

During her time at Cornell with Henry Guerlac, Marie had met most of his professional colleagues who were active in the History of Science Society, such as George Sarton, Bernard Cohen and others. She too became active in the HSS, but in 1957 turned down the editorship of Isis because she feared it would leave her too little time for her own research.

Rupert and Marie were elected Fellows of the British Academy in 1978 and 1994 respectively, and in 1981 they jointly received the Sarton Medal (the highest award of the HSS). Rupert was president of the British Society for the History of Science from 1966 to 1968.

From the mid-1950s onwards both Rupert and Marie were living the kind of busy academic lives that reduce a biographical sketch to a bibliography. Marie's temporal range was the greater: she wrote on late antiquity, on the long sixteenth century and on the nineteenth century. ${ }^{16}$ Apart from revising The Scientific Revolution, in history of science Rupert tended to stick to the seventeenth century, largely writing on Newton and people or problems connected with him, which were in plentiful supply. ${ }^{17}$ It tends to be original books that make most of a splash at the time, doubtless for a mixture of good and bad reasons, but as any experienced historian will have noticed, the works that prove most lastingly useful are usually those whose making involved less originality and more slog: such things as learned editions of manuscripts and correspondence. The Halls made a respectable number of contributions of this kind, among them brief items such as lectures by Hooke and a substantial collection of papers by Newton. ${ }^{18}$ They were also responsible for a learned edition of the huge correspondence of Henry Oldenburg, the first secretary of the Royal Society, ${ }^{19}$ and in the 1970 s Rupert also worked on an edition of the correspondence of Isaac Newton. ${ }^{20}$ It was not empty words when Rupert said he thought it was a historian's duty to make primary sources available to later generations of scholars. ${ }^{21}$

16 Marie Boas, 'Hero's “Pneumatica”: a study of its transmission and influence', Isis (1949) 40, pp. 38-48; and Hero of Alexandria, The Pneumatics, Introduction by Marie Boas Hall, London: MacDonald, 1971; Marie Boas Hall, The Scientific Renaissance, 1450-1630, London: Collins, 1962; Marie Boas Hall, All Scientists Now: The Royal Society in the Nineteenth Century, Cambridge: Cambridge University Press, 1984.

17 For instance, A. Rupert Hall, Philosophers at War: The Quarrel between Newton and Leibniz, Cambridge: Cambridge University Press, 1980; A. Rupert Hall, All Was Light: An Introduction to Newton's Opticks, Oxford: Clarendon Press, 1993; collected articles in A. Rupert Hall, Newton, His Friends and His Foes, Aldershot: Variorum, 1993.

18 A. Rupert Hall, 'Two unpublished lectures of Robert Hooke', Isis (1951) 42, pp. 219-230; A. Rupert Hall and Marie Boas Hall, Unpublished Scientific Papers of Isaac Newton: A Selection from the Portsmouth Collection in the University Library, Cambridge: Cambridge University Press, 1962.

19 A. Rupert Hall and Marie Boas Hall (eds.), The Correspondence of Henry Oldenburg, vols. 1-9 (1641-1673), Madison: The University of Wisconsin Press, 1965-1973; vols. 10-11 (1673-1675), London: Mansell, 1975; vols. 12-13 (1675-1677), London: Taylor and Francis, 1986.

20 The Correspondence of Isaac Newton, 4 vols., Cambridge: Cambridge University Press, vols 1-3 ed. Herbert Westren Turnbull, 1959-1961, vol. 4 ed. A. Rupert Hall and Laura Tilling, 1977.

21 Interview in Metascience, op. cit. (5). 